\title{
Fermentation Shared Resource
}

National Cancer Institute

\section{Source}

National Cancer Institute. Fermentation Shared Resource. NCI Thesaurus. Code C39403.

The Fermentation Shared Resource provides services for custom production,

purification, and maintenance of microorg anisms, microbial products, and other plant and animal cells for use in cancer research by Cancer Center investigators. 